\title{
Sexual Harassment: The Experience of Out-Of- School Teenagers in Benin City, Nigeria
}

\author{
Okoro F. I and Osawemen Obozokhai
}

\begin{abstract}
Out-of-school teenage sexual harassment is a problem for both boys and girls in our society today, and the effects of this experience can affect their lives negatively in later adult life. The data on sexual harassment, particularly those on the out-of-school teenage population in Nigeria are very scanty, as a result of the sensitive nature of, and the stigma attached to the subject. This study sought to investigate the experiences of out-of-school teenagers with regards to sexual harassment in Benin City, Edo State, Nigeria. A survey method was used whereby a questionnaire was employed since most of the teenagers could not read. A total of 650 youths (293 males and 357 females) participated in the study. The findings indicate that sexual harassment is common out there in the streets, to the extent that it was viewed as the norm in the society by the youths. For example, $296(83 \%)$ of all females and 152 $(62 \%)$ of all males had experienced one or more forms of sexual harassment. It was also found that more females (82\%) compared to $48 \%$ males experienced harassment and that anger was the most common response to the experience. The majority of the victims considered their assailants as abnormal and for the most part did not know how to handle the situation. The implications of these findings both for social/legal action and for health/ sex education are discussed. (AfrJ Reprod Health 2005; 9[3]:118-127)
\end{abstract}

\section{RÉSUMÉ}

Harcèlement sexuel: L'expérience des adolescents qui ne fréquentent pas l'école. Le harcèlement sexuel dont subissent les adolescents qui ne fréquentent pas l'école est un problème pour les garçons et les filles dans notre société aujourd'hui et les conséquences de cette expérience peut affecter leur vie d'une manière négative plus tard dans la vie adulte. Les données concernant le harcèlement sexuel, surtout par rapport à la population des adolescents qui ne fréquentent pas l'école au Nigéria, sont très maigres à cause de la nature sensible du sujet et le stigmate qu'on y attache. Cette étude a essayé d'examiner les expériences des adolescents qui ne fréquentent pas l'école à l'égard du harcèlement sexuel à BeninCity, Etat d'Edo, Nigéria. Nous nous sommes servi de la méthode d'enquête à l'aide d'un questionnaire parce que la plupart des adolescents ne pouvaient pas lire. Au total 650 jeunes (293 garçons et 357 filles) ont été enquétés. Les résultats ont montré que le harcèlement sexuel est chose commune dans la rue à tel point que les jeunes le considèrent comme la norme dans la société. Par exemple, 296(83\%) de toutes les filles et 152(62\%) de tous les garcons ont vécu l'expérience du harcèlement sexuel d'une manière ou d'une autre. Il a été découvert que plus de filles ( $82 \%)$ que de garcons (48\%) ont vécu le harcèlement sexuel et que la réaction chez eux a été toujours la colère. La majorité des victims ont considéré leurs aggresseurs comme des gens anormaux et dans la plupart des cas, ils ne savaient pas comment gérer la situation. Nous avons discuté les implications de ces résultats pour l'action sociale/légale et pour l'éducation de la santé et l'éducation sexuelle. (Rev Afr Santé Reprod 2005; 9[3]:118-127)

KEY WorDs: Sexual Harassment, Out-of-School Teenagers, Sub-Sabaran Africa.

Correspondence: Dr. (Mrs) F. I Okoro, Department of Physical and Health Education, University of Benin, Benin City 


\section{Introduction}

The United States Equal Employment Opportunity Commission (EEOC) defines sexual harassment as "unwelcome sexual advances, requests for sexual favours, and other verbal or physical conduct of a sexual nature". Sexual harassment has also been defined as a continuum of behaviours, with physical sexual assault at one extreme and non-verbal sexually suggestive behaviour at the other extreme ${ }^{1}$

In the African context, the continuum of behaviours range from unwanted touch, verbal intimidation, unwanted kiss, deception, drugging, attempted rape, rape, to cultural expectations that require girls to marry and sexually service men against their will. ${ }^{2,3}$

Gender issues are central to the understanding of teenage sexual harassment, and sex discrimination. Sexual harassment is a problem that plagues societies the world over. This problem once thought to be an issue only among females is also becoming a serious issue among males. The number of cases involving teenagers is increasing and will continue to do so, as more teenagers who are sexually harassed remain quiet. ${ }^{2}$ Most of the literature on sexual harassment shows that over $90 \%$ of the time, males are the perpetrators of sexual harassment against females. $^{4-7}$

The American Association of University Women (AAUW), listed 14 types of sexual harassment and asked 1,600 teenagers to identify which of them they had experienced. The list include: sexual comments, jokes, gestures or looks; being called names, e.g. prostitute; showed, gave or left you sexual pictures, photographs, illustrations, messages or notes; spread sexual rumours about you; flashed or "mooned" you; touched, grabbed, or pinched you in a sexual manner; pulled your clothes off or down; blocked your way or covered you in a sexual way; intentionally brushed against you in a sexual way; etc. ${ }^{8}$

The harasser is not always older than the victim, and the victim is not always a member of opposite sex. Teenagers seem to be abused more often than adults, both by their legal guardians, older relatives, and in some instances by their parents.

The American Association of University Women (AAUW), also reported that four of five teenagers reported being harassed, and of those, $79 \%$ stated that the harassment was by a peer. This was the first document of a high level of sexual harassment experienced by teenage boys and girls who are out-of- school. ${ }^{9}$ These data are different from those in the school-place and workplace literature that indicate the sexual harassment of males in the workplace or school to be between $2 \%$ and $15 \%$, while that of females ranged between $40 \%$ and $53 \% .^{10-14}$

In a study of sexual harassment of teenagers it was observed that many teenagers believed that sexual harassment was the norm in the society; the investigators also reported that there had been numerous reports of sexual harassment and rape on the streets. They concluded that in an environment that condones sexual harassment, everyone was a victim, and not just those who are direct targets of the harassment. In this instance, all teenagers come to see their societies as being unsafe, hostile and intimidating and may alter their own behaviours in an attempt to decrease their sense of vulnerability. They were of the view that the prevalence of sexual harassment in societies interfered with and inhibited the development process of these teenagers. ${ }^{4,6}$

In some places, short courses on managing sexual harassment are provided to help students define sexual harassment, recognise it as a form of discrimination and learn to deal with it effectively but there has been no efforts to do likewise for out-of-school teenagers (i.e. youths 13 - 19 years old who are not currently in any formal educational settings. They may have gone through primary school (partially or in full); may have left secondary school without certification or completed secondary school but have neither 
120 African Journal of Reproductive Health

gone beyond that nor are they in the labour force. (For the most part they have not acquired any work skills.) These teenagers are out on the streets trying to eke a living either for themselves or for their families. They roam the streets for the greater part of the day, often presenting figures of vulnerable individuals to dangers in a society. They are used to carry out petty crimes, unimaginable sexual practices and are more often than not sexually harassed. This has become a most disturbing trend with resultant psychological, mental and emotional distraught. ${ }^{6}$

Following their study of the experience of sexual coercion among adolescents (students and apprentices) in Ibadan some researchers who found that both males and females were victims of coercion with females being disproportionately affected, had recommended multiple intervention strategies including skills acquisition training for young persons, sensitisation workshops for training health workers, and media advocacy for the public to challenge stereotypes that favour sexual coercion of adolescents. ${ }^{3}$

Same investigators also found in another study of the perception of sexual coercion of young people, that young people are unable to communicate effectively with one another and to resolve differences. The results suggested the need for life skill acquisition training that facilitates communication, and teaches alternatives to coercion as a means of resolving conflict on sexual relations, as well as teaches respect for sexual and reproductive rights while providing at the same time information to victims of appropriate services, support and referrals. ${ }^{3}$ There is, however, the need to translate these recommendations/theories into action.

\section{Problem Statement}

An increasing amount of sexual harassment is directed at out-of-school teenagers who are often defenceless against the onslaught of their harassers. Thus, these teenagers grow up with all sorts of disturbed behaviours and personality mixes and society becomes the worse-off for it.
The unclear definition and misinterpretations of sexual harassment have led many to believe that the amount of sexual harassment that occurs to out-of-school teenagers is minimal. The problem is further compounded by the fact that most of the data available on teenage sexual harassment are often those of teens in formal school settings. Therefore, there is a dearth of information on the experiences of out-of-school teenagers, particularly here in Nigeria where very few studies have been carried on this target population on the subject matter, due to its sensitive nature and the stigma often associated with it. Hence the need for further research in this area in order to obtain and document such data. The data available is mainly from reproductive health surveys which have their limitations and are very likely to underestimate the prevalence of sexual harassment in this population group. ${ }^{15}$

The purpose of this study, therefore, is to find out the experiences of out-of-school teenagers concerning sexual harassment. In order to do this the following research questions have been drawn up:

(1) what is the nature of the sexual harassment experienced by out-ofschool teenagers?

(2) What factors expose these teenagers to sexual harassment?

(3) How do these teenagers perceive the problem?

(4) What are their reactions to the problem and how do they attempt to deal with it?

(5) Is there a gender difference in these experiences?

It is hoped that this study will contribute to data generation on the subject of teenage sexual harassment of which there is a dearth. Moreover, the findings, if well disseminated, will be useful in sharpening the awareness of lawmakers, social

African Journal of Reproductive Health Vol. 9 No.3 December 2005 
workers and adolescent programme planners. Understanding the dynamics of teenage peer sexual harassment, for instance, has important theoretical and practical implications for researchers and practitioners in educational and mental health environments. ${ }^{13}$

\section{Research Method}

The study was a descriptive one and so the survey design was adopted. The site of the study included in Egor Local Government Area (LGA) - (Uselu Motor Park, Uselu Market, the ELF, African Petroleum (AP) and Uselu Shell Filling Stations).

In Oredo Local Government Area (LGA) - New Benin Market along Upper Lawani and Upper Mission Roads; Oba Market area along Lagos Street, the Iyaro Motor Park, around the King Square by Forestry, Bata and First Bank).

In Ikpoba-okha Local Government Area (LGA) - (Agbor Motor Park, and the Amusement and Ramat Parks).

The choice of these locations was advised by the fact that those are the areas where there is usually a concentration of people either buying and selling or travelling. Hence, these teenagers also congregate around there to hawk and sell their commodities/wares, mainly food, snacks, beverages, toiletries and the like.

The population consisted of out-of-school teenagers of both sexes in the three local government areas of the Benin metropolis, namely: Egor, Oredo and Ikpoba-Okha. In selecting the out-of-school teenagers for the study, specific areas within the LGA where they are likely to be found were used, including motor parks, markets, petrol stations, mechanics and other workshops, etc. as indicated above.

Approximately 650 out-of-school teenagers participated in this study. At each location, starting with the first teenager encountered, every third one was selected. At the end of the selection, the youths were intimated to the purpose of the assembly and asked to indicate their willingness to participate. There were altogether 708 teenagers of which $650(91.8 \%)$ agreed to participate, and so were recruited as the sample for the study. The sample though a systematic random sample was also one of convenience whereby at each site only those teenagers who indicated an interest/willingness to participate were recruited. Though not a random sample of teenagers in Benin City, the areas and the teenagers selected were representative of the outof-school teenagers by geographical area.

The instrument for the study was a questionnaire designed to be completed by the trained research assistants and the two investigators. It consisted of 20 questions of the Yes/No type adopted from the (AAUW)'s Educational Foundation document and questions. It was in 2 sections. The first part sought biographical information such as age, sex, parental background, and area of residence, while the other part sought information on their experiences concerning sexual harassment. The experiences were in four categories - verbal intimidation/threats; physical unwanted touch of private areas, hand holding or kiss; deceit tending towards attempted sexual demand or activity; and actual sexual activity (intercourse), by coercion or force.

The instrument possessed a high content validity, which was ensured through critical evaluation by two juror in health education, reevaluation and restructuring of the questions based on the feedback. The reliability was ensured through a test-retest method of the results of an earlier pilot study and had a correlation coefficient value of 0.82 .

The face-to-face interview method was used. The researchers approached the out-of-school teenagers at each site, told them what they were about (i.e. collecting information as was agreed upon that will be used to address their plight) and solicited their cooperation and participation. An incentive of 10 Naira each was promised for participation and was provided at the end of the interview. Moreover, confidentiality was assured through anonymity, as no names were required.

The questions were then read out, ques- 
122 African Journal of Reproductive Health

tion by question and the respondents gave their answers to each question while the researcher/ assistants ticked ([ -) the appropriate choices accordingly. Occasionally, there was need for explanations by the researchers whenever there was any difficulty with understanding what was meant/required.

The data was coded and analysed in the computer, using the statistical package for the social sciences (SPSS) - students version. The analysis is descriptive, using frequencies and percentages. The results are as presented.

\section{Results}

A total of 650 out-of-school teenagers responded to the questionnaire. Of these, 293 (45\%) were males, while 357 (55\%) were females. They were all between 13 and 16 years with an average age of 14 years for the females and 15 years for males. The profile of the respondents is presented in Table 1.

Only $133(45.4 \%)$ males and 159 (44.5\%) females of the respondents finished primary school, while $88(30 \%)$ of the males and 124 $(34.7 \%)$ of the females had attained less than primary 6 education; with $28(9.6 \%)$ males and $26(7.3 \%)$ females having had no education at all. Most of these youths having either dropped out of school or attended very irregularly.

In terms of economic activity, they all are engaged in some form of trade, predominantly hawking. The majority of the females 215 (60\%) are engaged in the selling of snacks and food such as peanuts, plantain chips, gala, bread and other baked items, while 67 (23\%) of the boys are similarly engaged. About equal percentage 126 $(43 \%)$ and $139(39 \%)$ of males and females respectively sell beverages such as soft drinks, fruit juice and water. However, 100 (34\%) males are engaged in other unskilled labour such as wheelbarrow pushing, loading and off-loading of lorries, while only $3(.8 \%)$ of females are similarly engaged.

The results also show that more than half

Table 1: Profile of the Out-of-School Respondents Aged 14 - 16

\begin{tabular}{|c|c|c|c|c|}
\hline & \multicolumn{2}{|c|}{ Males } & \multicolumn{2}{|c|}{ Females } \\
\hline & $\mathrm{N}=293$ & $(45 \%)$ & $\mathbf{N}=357$ & $(55 \%)$ \\
\hline Mean Age & 15 & & 14 & \\
\hline \multicolumn{5}{|l|}{ Educational Attainment: } \\
\hline None & 28 & $(9.5)$ & 26 & $(7.3)$ \\
\hline$<$ Primary 6 & 88 & $(30)$ & 124 & $(34.7)$ \\
\hline Finished Primary 6 & 133 & $(45.4)$ & 159 & $(44.5)$ \\
\hline$<$ Junior Sec. Sch. (JSS) & 35 & $(11.9)$ & 35 & $(9.8)$ \\
\hline Finished (JSS) & 9 & $(3.1)$ & 13 & $(3.7)$ \\
\hline$<$ Senior Sec. Sch. (SSS) & 0 & $(0)$ & 0 & (0) \\
\hline Finished (SSS) & 0 & $(0)$ & 0 & $(0)$ \\
\hline Total & 293 & $100 \%$ & 357 & $(100 \%)$ \\
\hline \multicolumn{5}{|l|}{ Economic Activity: } \\
\hline None & 0 & 0 & 0 & 0 \\
\hline Hawking (Food and Snacks)(Gala, Chipps) & 67 & (23) & 215 & $(60)$ \\
\hline Hawking Beverages & 126 & (43) & 139 & 39 \\
\hline $\begin{array}{l}\text { Other (Manson's Hand, Wheelbarrow } \\
\text { pushing }\end{array}$ & 100 & $(34)$ & 3 & 1 \\
\hline Total & 293 & $(100 \%)$ & 357 & 100 \\
\hline
\end{tabular}


of the respondents 368 (56.6\%) were from homes where the fathers were either unemployed or engaged in menial jobs such as truck/wheelbarrow pushing, day or night guards, and other forms of unskilled labours such as off-loading of wares from trucks or mansion's handymen. Another 109 (16.8\%) came from homes where the fathers were either farmers or engaged as farm hands, while $87(13.3 \%)$ had fathers who were businessmen. Some $54(8.3 \%)$ of the respondents' fathers were teachers and a token $32(5 \%)$ had fathers who were civil servants.

While the respondents' mothers' occupation indicated $65(10 \%)$ civil servants; $87(13.4 \%)$ farming; $216(33.2 \%)$ business or trading; 108 $(16.6 \%)$ teaching and $174(26.8 \%)$ were full time housewives.

On the whole, the results show that only a few of the respondents $86(13.3 \%)$ were from homes where the fathers had steady incomes from being civil servants or teachers, while 17.3 (26.6\%) had mothers who had such steady incomes. This is an indication that poverty was one of the main reasons why these teenagers were out there, either trying to solely provide for the family or to augment their parents' incomes.

\section{Nature of Sexual Harassment}

Findings indicate that $296(83 \%)$ of all females and $182(62 \%)$ of all males had experienced one form of sexual harassment or the other. As to the nature of sexual harassment experienced by these out-of-school youths, it was found that verbal assaults were most common, particularly for the females 296 (83\% compared to 62 (21\%) for the males. This is followed by unwanted touch of various forms - touch of sensitive/private parts $71 \%$ for the females and $43 \%$ for males, while touch of hand was $74 \%$ for the females, and $61 \%$ for the males.

Boys, however, experienced pulling down of their clothes in a sexual way more than girls $60 \%$ for males and $48 \%$ for females. Fifty-eight percent $(58 \%)$ of the females and $26 \%$ of the males had experienced attempts of forced but unsuccessful sex activity, while $19 \%$ of females and $16 \%$ of males had experienced actual forced sexual intercourse (rape). On the whole, the findings indicate that both males and females outof-school teenagers are victims of sexual harassment, with females being disproportionately affected (Table 2).

As to the factors that exposed the teenagers to sexual harassment it was found that being on

Table 2: $\quad$ Sexual Harassment Experiences of Respondents

\begin{tabular}{llllr}
\hline \multirow{2}{*}{ Type of Experience } & \multicolumn{4}{c}{ Respondents } \\
\cline { 2 - 5 } & \multicolumn{3}{c}{ Males } & \multicolumn{2}{c}{ Females } \\
\cline { 2 - 5 } & \multicolumn{1}{c}{$\mathbf{N}=\mathbf{2 9 3}$} & $\mathbf{0}$ & $\mathbf{N}=\mathbf{3 5 7}$ & $\mathbf{\%}$ \\
\hline Any form of harassment & 182 & $(62 \%)$ & 296 & $(83 \%)$ \\
Verbal threats/abuses (name calling) & 62 & $(21 \%)$ & 293 & $(82 \%)$ \\
Pulling on clothes in sexual manner & 176 & $(60 \%)$ & 172 & $(48 \%)$ \\
Touch of hand & 179 & $(61 \%)$ & 264 & $(74 \%)$ \\
Unwanted touch of private parts (breast, buttocks, etc.) & 126 & $(43 \%)$ & 253 & $(41 \%)$ \\
Unwanted kiss & 56 & $(19)$ & 82 & $(23)$ \\
Attempted forced sex & 76 & $(26 \%)$ & 207 & $(58)$ \\
Actual forced sex (oral, anal) & 47 & $(16 \%)$ & 68 & $(19 \%)$ \\
\hline
\end{tabular}

African Journal of Reproductive Health Vol. 9 No.3 December 2005 
124 African Journal of Reproductive Health

the streets increased the chances of being harassed, as some of the teens stated that they did not have similar experiences when they were going to school. These teenagers indicated that being in school would prevent them from being sexually harassed.

However, a few of the girls did observe that in their own words, "that used to happen in school sometimes but not so much". Some of these verbal reports also point to the fact that some of the respondents must have dropped out of school or at least attended school at some point.

A breakdown of places where the harassment occurs most in their views is as presented in Table 3.

Generally, being out there in the streets increases the risk of sexual harassment by $69 \%$ for the females and $63 \%$ for the males; as opposed to being in school where it is $34 \%$ for the females and 19\% for the males. Even the home is not safe for these vulnerable teens as $18 \%$ and $4 \%$ of the harassment for the females and males respectively occur in the homes.

Over half of the males 185 (63\%) said that being on the streets increased the chances of their being sexually harassed, while 228 (64\%) of the females agree that being in school would prevent sexual harassment. There does not seem to be much gender differences in their opinion. Interestingly though, none of the respondents saw their social-economic status or condition as a factor.
Table 4 represents perception of and how they handled the problem of sexual harassment. For example, when asked about how they saw the problem (perception), most of them saw it (sexual harassment) as a normal occurrence, though it made them feel defiled or dirty. This view was presented by 120 (41\%) of the males and $136(38 \%)$ of the females.

Inquiring into how these teenagers handled the situation revealed that they felt angry with both themselves and their assailants. Most of the females $186(52 \%)$ and $108(37 \%)$ of the males felt angry with themselves, while 141 (48\%) of the males and 271 (76\%) of the females felt angry with their assailants (Table 4). It is interesting to note here that almost twice as many females as males directed their anger appropriately, that is, towards their assailants.

This finding also agrees with that of the AAUW Educational document (1993) in which it was reported that sexually harassed teenagers reported amongst other things feeling angry, upset and threatened, which they concluded contributed to lowered self-esteem and confidence. ${ }^{9}$

It was also found that these out-of-school teenagers, especially the females, did not know how to deal with the problem, i.e. they had no idea where to get help from or how to handle the situation. A small number 117 (40\%) males and $96(27 \%)$ of the females said they could manage somehow by avoiding the situation or reporting to someone. That "someone",

\section{Table 3: Respondents views of where harassment often occurs}

\begin{tabular}{lllll}
\hline Places & \multicolumn{3}{c}{ Males } & \multicolumn{2}{c}{ Females } \\
\cline { 2 - 5 } & $\mathrm{N}=293$ & $(45 \%)$ & $\mathrm{N}=357$ & $(55 \%)$ \\
\hline Out in the streets (General) & 185 & $(63 \%)$ & 246 & $(69 \%)$ \\
Free way (Roads) with "go slow" & 32 & $(11 \%)$ & 46 & $(13 \%)$ \\
Motor parks & 114 & $(39 \%)$ & 154 & $(43 \%)$ \\
Fuel stations & 44 & $(15 \%)$ & 46 & $(13 \%)$ \\
Markets & 15 & $(5 \%)$ & 29 & $(8 \%)$ \\
Schools & 56 & $(19 \%)$ & 121 & $(34 \%)$ \\
Homes (Residents) & 12 & $(4 \%)$ & 64 & $(18 \%)$ \\
\hline
\end{tabular}


Sexual Harassment: The Experience of Out-Of-School Teenagers in Benin City, Nigeria

Table 4: Respondents Perception of and ways of handling the problem (Sexual Harassment)

\begin{tabular}{lllll}
\hline Perception of Problem & \multicolumn{2}{c}{ Males } & \multicolumn{2}{c}{ Females } \\
\cline { 2 - 5 } & $\mathrm{N}=293$ & $(45 \%)$ & $\mathrm{N}=357$ & $(55 \%)$ \\
\hline As Normal & 231 & $(71 \%)$ & 14 & \\
As Abnormal & 53 & $(18 \%)$ & 57 & $(16 \%)$ \\
Unsure & 9 & $(3 \%)$ & 7 & $(2 \%)$ \\
\hline Total & 293 & $(100 \%)$ & 357 & $(100 \%)$ \\
\hline Feelings (Response) & & & & \\
\hline Anger directed at self & 141 & $(48 \%)$ & 271 & $(76 \%)$ \\
Upset & 108 & $(37 \%)$ & 186 & $(52 \%)$ \\
Threatened & & & & \\
Dirty (Defiled) & & & & \\
Action Taken & 182 & $(62 \%)$ & 239 & $(67 \%)$ \\
\hline No Action & 117 & $(40 \%)$ & 96 & $(27 \%)$ \\
Try to avoid situation & \multicolumn{5}{c}{} & \\
\hline Reported to authority figure: & 0 & 0 & 4 & $(1 \%)$ \\
\hline Parents & 32 & $11 \%$ & 93 & $(26 \%)$ \\
Peers/friends & 0 & 0 & 0 & $(0)$ \\
Teachers & 9 & $(3 \%)$ & 18 & $(5 \%)$ \\
Religious leader (Pastor) & & &
\end{tabular}

however, turned out to be their peers/friends (Table 4).

With regards to the question of gender differences in the experiences of the teenagers it was found that generally more female teenagers are harassed than males; that is, over half of the females in the study $83 \%$ in contrast to $62 \%$ males. This finding also is in keeping with those of the AAUW as indicated in its reports, "Hostile Hallways"; and of another study. ${ }^{16}$ According to the latter, gender, power hierarchy fall broad under social justice issues, in which sexual harassment is viewed as sex discrimination. The fact that peer sexual harassment can be viewed as supporting a gendered hierarchy contributes to the need for education and training that encourages a more egalitarian environment and discourages discrimination against girls. He also added that it was vital to note, however, that all teens are affected by these behaviours and that there should be legal means established to safeguard these out-of-school teenagers. Another report indicated a number of views that support a legal and democratic understanding of sexual harassment while ensuring that 'individual teens are protected and a positive learning environment encouraged'. ${ }^{17}$

\section{DISCUSSION}

This study has provided an insight into the natural and experiences of out-of-school teenagers with regards to sexual harassment in Benin City. The findings indicate a high prevalence, with females being disproportionately affected being that $83 \%$ of all females and $62 \%$ of all males reported experiencing one or more forms of sexual harassment agree with data from existing studies. ${ }^{7,9,16}$

As to the predisposing factors to sexual harassment it was found that being out there in the streets increased the risk of being harassed as was reported by more than half of the teenagers of both sexes. In fact, $64 \%$ of the females believe that being in school would prevent or reduce the chances of their being sexual harassed. 
126 African Journal of Reproductive Health

Interestingly, however, neither the males nor females saw their socio-economic status or condition as a factor; whereas it is obvious that the reason why they are out there is to try to eke a living for themselves or to support the family income. This is a vital point because poverty is implicated in why parents would send their underaged children out into the streets to try to earn an income instead of schooling.

Another striking finding is that these out-ofschool teenagers perceive sexual harassment as a normal occurrence in the society, even though it made them feel bad and angry. This finding also tallies with other findings where it is observed that many teenagers believe sexual harassment to the room in the society. ${ }^{4}$

Inquiring into how these teenagers handled the situation in terms of how they felt and what they did in response to the experience of harassment reached they felt angry both with themselves and with their assailants but beyond that the majority did not know what to do. It is interesting to note that almost twice as many females as males directed such anger at themselves, when they felt upset and threatened which some investigators have reported contributed to lowered self-esteem and confidence.

Some studies have shown that many teenagers report performance difficulties as a result of sexual harassment including absenteeism, loss of friends, tardiness and truancy which in turn can lead to fewer career choices and decreased or lost economic opportunities and possible job failure.

The fact that these teenagers particularly the females did not know how to deal with the problem in terms of not knowing how to handle the situation or where to get help from has great implication for education, particularly in the form of awareness creation, training and skill acquisition.

\section{Implications for Action}

The findings from this study have several implications for various programmes requiring cer- tain intervention strategies.

There is a need for the establishment of poverty alleviation programmes by the government at all levels. Poverty seems to be a major cause of many social ills in our society today. Why would parents send out or allow their under-aged children into the streets if not out of desperation? Such programmes should be community-based if they are to succeed. ${ }^{20}$

Understanding the dynamics of teenage sexual harassment has vital theoretical and practical implication for researchers and educational and mental health practitioners. Peer sexual harassment of out-of-school teenagers has only been recently documented and is being viewed as only solvable through a legal process. $^{21}$

The fact that peer sexual harassment can be viewed as supporting a gendered hierarchy adds to the need for education and training that encourages a more egalitarian environment and discourages discrimination against girls. There should be legal means set up to safeguard these out-ofschool teenagers. There are, however, very scant if any research data to guide government on how to proceed or how effective there measures are.

The mass media can play a very vital role of advocacy and public enlightenment so that all stake holders - community leaders, parents, teachers, health service providers on the teenagers themselves — will be sensitised in order to challenge cultural practices and stereotypes that favour sexual harassment. The need to be aware of the magnitude and the consequences of the practice on the victims and help to minimize the associated stigma.

On the whole, the findings indicate that there are a lot of these vulnerable teens out in the streets and that they are constantly being sexually harassed; and that they find the experience very traumatic as indicated by the reported negative emotions they experienced. The mere fact that they lack the training to deal with the situation has great implications both for social/legal action and for health/sex education. The need for poverty alleviation for families is urgent as is that for creating/fostering a positive climate for the develop-

African Journal of Reproductive Health Vol. 9 No.3 December 2005 
ment of these teenagers. Health educators and social workers need to develop community direct services and education programmes that address teenage sexual harassment as a mental health issue.

\section{REFERENCES}

1. U. S. Equal Employment Opportunity Commission (EEOC) Guidelines on Discrimination Because of Sex. Federal Register. 45, 74676 - 74677, 1980.

2. Heise I, Moore K, and Toubia N. Sexual Coercion and Reproductive Health; a focus on research. The Population Council, New York, 1995.

3. Ajuwon, A. J, Olley, B. O. Akin-Jimoh, I. and Akintola, O. Experience of Sexual Coercion among Adolescent in Ibadan, Nigeria. African Journal of Reproductive Health 5(3): 12 - 31. December 2001.

4. Strauss, S. and Espeland, P. Sexual Harassment and teens. Minneapolis: Free Spirit, 1992.

5. Langelan, J. M. Back Off. New York: Simon and Schuster, 1993.

6. Stein, N.; Marshall, L. N.; and Tropp, L. R. Secrets in Public: Sexual Harassment in our Schools. Wellesley, MA: Wellesley College, Centre for Research on Women, 1993.

7. Heise, L, Ellsberg M and Gotten Moeller M. Ending Violence against women. Population Reports Series L, No. 11, 1999.

8. American Association of University Women (AAUW). Educational Foundation How schools short-change girls. Wesley, M. A.: Wellesly College Center for Research on Women, 1992.

9. American Association of University Women Foundation Hostile Hallways: The AAUW survey on sexual harassment in American Schools (Research Report 923012) Washington, DC. Harris/Scholastic Research, 1993.

10.a U. S. Merit Systems Protection Board, Sexual Harassment of Federal Workers: Is it a problem? Washington, DC. U. S. Government Printing Press, 1981.

10.b U. S. Merit System Protection Board, Sexual Harassment of Federal Workers: An Update. Washington, DC. U. S. Government Printing Office, 1987.

11. Metha, A. and Nigg, J. Sexual Harassment on Campus: An Institutional Response. Journal of the National Association for Women Deans, Administrators and Counsellors, 46, 9 15, 1983.

12. Gutek, A. B. Sex and the Workplace. San Francisco: Jossey - Barr, 1985.

13. Fitzgerald, F. L.; Shullman, S.; Baily, N.; Richards, M.; Swecker, J; Gold, Y; Oremerod, A. J. and Weitzman, L. The Incidence and Dimensions of Sexual Harassment in Academia and the Workplace. Journal of Vocational Behaviour, 32.152 - 175. San Francisco: Jessey - Barr, 1988.

14. Pryor, B. J.; La Vite, M. C. and Stoller, L. M. A Social Psychological Analysis of Sexual Harassment: The Person/Situation Interaction. Journal of Vocational Behaviour 42, pp. 68 - 83, 1993.

15. Ellsberg M, Heise L, Pena R, Agurto S, and Winkvist A. Researching domestic violence against women: Methodological and ethical issues. Studies in family planning, 32 (1): 1 -16, 2001.

16. Beauvais, K. Workshops to Combat Sexual Harassment: A Case of changing attitudes. University of Michigan, Ann-Arbor, 1986.

17. Licata, B. J. and Popovich, M. P. Preventing Sexual Harassment: A Positive Approach. Journal of Training and Development, 1987.

18. Khan, N. Sexual and Physical Abuse: a threat to reproductive and sexual health. Sexual Health Exchange, 1 - 3, 1998.

19. Allan Guttmarcher Institute. Into a new world: Young women's sexual and reproductive lives. New York, 1998.

20. Riddle, P. and Johnson, A. G. Sexual harassment: What role should Health Educators play? Journal of Vocational Behaviour No. 150, 1983. 